\title{
Ocular Morbidity Among Chepang Children, An Indigenous Ethnic Group of Nepal
}

\author{
Raju Kaitit ${ }^{1 *}$, Manish Dahal ${ }^{1}$ and Bikash Khatri ${ }^{2}$ \\ ${ }^{1}$ Consultant Optometrist, Nepal Eye Hospital, Nepal \\ ${ }^{2}$ Consultant Optometrist, Bhaktapur Hospital, Nepal
}

Submission: July 29, 2020; Published: August 04, 2020

*Corresponding author: Raju Kaiti, Consultant Optometrist, Nepal Eye Hospital, Kathmandu, Nepal

Abstract

Background: Chepang are the indigenous community inhabiting at mountain region of central Nepal sharing Mongolian features. Their literacy rate is below average and economic state is also miserable. Overall, this community is very backward and is the poorest of Nepal's poor. The prevalence of ocular abnormalities in Chepang has rarely been reported. A very little is known about the ocular morbidity status among Chepang children.

Method: A cross-sectional study was carried out to find the prevalence of refractive error and other ocular morbidities among Chepang children. A complete eye examination was carried out in all children including slit lamp examination, fundus examination, retinoscopy and subjective refraction.

Result: Of 120 children, refractive error was present in $18(15 \%)$ children. The prevalence of myopia (spherical equivalent, $-0.50 \mathrm{D}$ or more in either eye), astigmatism ( $\geq 0.75 \mathrm{D}$ ), and hyperopia ( $+0.50 \mathrm{D}$ or more) was $4.1 \%, 6.6 \%$, and $4.1 \%$ respectively. Of 120 children, $2(1.67 \%$ ) had amblyopia, $4(3.33 \%)$ had cataract, $1(0.83 \%)$ had nystagmus, $2(1.67 \%)$ had corneal opacity, $8(6.67 \%)$ had blepharitis, $4(3.33 \%)$ had conjunctivitis. The overall prevalence of ocular morbidity was $32.5 \%$

Conclusion: Ocular morbidity is more prevalent among chepang children and is a public health concern among these indigenous populations. Keywords: Chepang; Children; Eye examination; Prevalence; Refractive error

\section{Introduction}

Ocular morbidity is considered as one of most under diagnosed and undertreated public health problems in many developing nations especially in Asia [1-3]. The commonest ocular morbidity reported is refractive error. Refractive error is one of the most common causes of visual impairment around the world and the second leading cause of treatable blindness [4]. 2.3 billion people are estimated to be living with this problem [4-6]. Uncorrected refractive errors are the most common cause of visual impairment in children in all regions, affecting an estimated 12.4 million children which has been documented in series of populationbased, multi-country Refractive Error Study in Children (RESC) surveys in Nepal, China, Chile [7-9]. Incidence of myopia in children is multiplying globally is what now an 'epidemic' in East Asia, Europe and United States [6]. An estimated 153 million people over 5 years of age are visually impaired as a result of uncorrected refractive errors, of which 8 million are blind. Approximately 12.4 million children in the age group 5-15 years are visually impaired from uncorrected or inadequately corrected refractive errors, estimating a global prevalence of $0.96 \%$ [7-10]. Poor vision and an inability to read material on the chalkboard due to refractive error can profoundly affect a child's participation and learning in the classroom [11].

In Nepal, an estimated 1,013,041 children less than 16 years of age (prevalence among under 16 age group assumed to be $10 \%$ based on different studies varying from $3-20 \% ; 1,164,053$ persons between 16-35 years of age have uncorrected refractive error for distance (estimated prevalence 15\%) according to midterm review of Nepal Blindness Survey 2010 [12-14] Apart from refractive error, anterior and posterior segment abnormalities have also been reported in abundant cases in many screening camps and school screenings.

Chepang are the indigenous community inhabiting at mountain region of central Nepal sharing Mongolian features $[15,16]$. They live in caves and thatched houses. Poverty, lack of education, poor infrastructure, the community are often in bad health. The health seeking practices among the chepang community is very poor which brings complication in the mother's and child health. The children are deprived from good and balanced nutrient therefore they suffer from disease like pneumonia, diarrhea, typhoid and many stillborn diseases which ultimately makes child mortality 
high [15-17]. Overall, this community is very backward and is the poorest of Nepal's poor.

Kanda is located at Chitwan covering $12345 \mathrm{sq} \mathrm{km}$. The village is situated at the top of the mountain that lacks access to roadways and other infrastructures. One must walk at least for 9 hours to reach Kanda village. Poverty and illiteracy are the identity of chepang village located at Kanda. To the best of our knowledge not much work is done in the Chepang school going children and very little is known about the prevalence of refractive errors among these indigenous population. Pokharel et al. in their study found the prevalence of refractive error to be very little. Of 97 children, 7 had myopia and the commonest complaint observed was watering followed by ocular pain and complaints of diminution of vision for near [18]. Our study will help in assessing the refractive status of these children as well as increasing the awareness and better planning of eye care services in these remote areas. Early detection of reflective error and its timely and proper correction saves permanent ocular morbidity.

\section{Methods and Methodology}

\section{Ethical approval}

The principles outlined in the Declaration of Helsinki were followed. Consent was obtained from the parents for the study after explanation of the nature and possible consequences of the study.

\section{Research place and study design}

A total of 120 children attending primary schools in Kanda were included for eye examination. The school was contacted in advance by local people who informed them about the eye examination campaign. All parents were informed prior to the date of examination about the eye screening activity and that all children attending the school would be examined. The study was cross-sectional, with the objective of ascertaining prevalence of ocular morbidity especially, the prevalence of refractive errors.

\section{Examination}

The students underwent the following examinations:

a) Uncorrected, presenting and best corrected visual acuity was assessed using Snellen vision chart at 6 meter distance.

b) Retinoscopy and subjective refraction were performed in every child. Cycloplegic refraction was carried out in all cases with $1 \%$ cyclopentolate administered every 10 minutes for 3 times. Wet retinoscopy was carried out after 1 hour of instillation of 1 st drop.

c) Anterior segment examination was carried out with the help of a torch light and portable slit lamp biomicroscope.

d) Fundus evaluation was done with a direct ophthalmoscope. Fundus evaluation with dilated pupil was carried out in all required cases. e) Extraocular movements and cover tests were performed using torch light, and convergence was tested using RAF rule.

f) The following criteria were used to classify the refractive error. [14]

Hypermetropia:

g) If refractive error is of magnitude $\geq+0.50$ D. This was further classified as low hypermetropia $(>+0.50 \mathrm{D}$ to $<+$ 3.0D), moderate hypermetropia $(>+3.0 \mathrm{D}$ to $<+6.0 \mathrm{D})$ and high hypermetropia (>+6.0D).

Myopia:

h) If refractive error is of magnitude $\geq-0.50 \mathrm{D}$. This was further classified as low myopia ( $>-0.50 \mathrm{D}$ to $<-3.0 \mathrm{D})$, moderate myopia (>-3.0D to <-6.0D) and high myopia (>6.0D).

Astigmatism:

i) Any cylindrical error $\geq \pm 0.5$. Astigmatism was further classified as simple myopic astigmatism, simple hyperopic astigmatism, compound hypermetropic astigmatism, compound myopic astigmatism and mixed astigmatism.

\section{Statistical analysis}

Data analysis was performed using the software SPSS for Windows version 19.0 (IBM, Armonk, NY, USA).

\section{Result}

The study population consisted of 120 children between 6 to 14 years old of which 78 (65\%) were male and 42 (35\%) were female. The most common ocular morbidity was refractive error (15\%) followed by blepharitis (6.67\%). Of 120 children, $2(1.67 \%)$ had amblyopia, $4(3.33 \%)$ had cataract, $1(0.83 \%)$ had nystagmus, $2(1.67 \%)$ had corneal opacity, $8(6.67 \%)$ had blepharitis, $4(3.33 \%)$ had conjunctivitis. Figure 1 shows the specific ocular morbidities present among chepang children. Myopia (spherical equivalent, -0.50 diopters [D] or more in either eye) affected $4.1 \%$. Hyperopia $(+0.50 \mathrm{D}$ or more) affected $4.1 \%$ in all age groups. Astigmatism ( $\geq 0.75$ D) was present in $6.6 \%$ of all children. Astigmatism was found to be more prevalent among children. Refractive error was equally prevalent on both male and female (7.5\%). Table 1 shows the prevalence of specific refractive error.

Table 1: Prevalence of refractive error by age and sex in chepang children.

\begin{tabular}{|c|c|c|c|c|}
\hline Category & N & Myopia & Hyperopia & Astigmatism \\
\hline $\begin{array}{c}\text { Age } \\
\text { Group }\end{array}$ & \multicolumn{4}{|l|}{} \\
\hline $6-10$ & $50(41.6 \%)$ & $3(6 \%)$ & $2(4 \%)$ & $5(10 \%)$ \\
\hline $10-14$ & $70(58.4 \%)$ & $2(2.85 \%)$ & $3(4.2 \%)$ & $3(4.28 \%)$ \\
\hline Sex & \multicolumn{5}{|l}{} \\
\hline Male & $78(65 \%)$ & $2(2.56 \%)$ & $3(3.84 \%)$ & $4(5.1 \%)$ \\
\hline Female & $42(35 \%)$ & $3(7.1 \%)$ & $2(4.7 \%)$ & $4(9.5 \%)$ \\
\hline
\end{tabular}




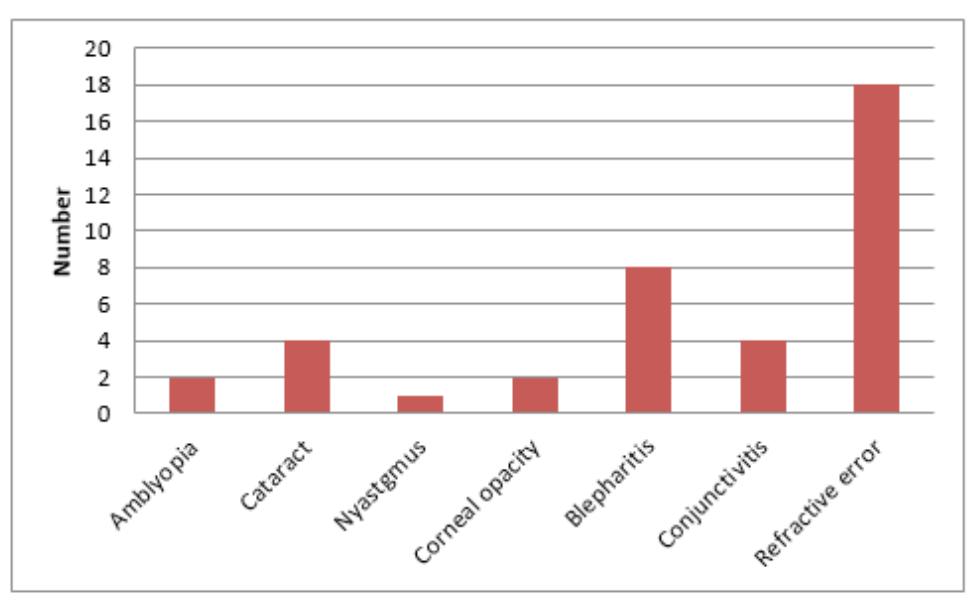

Figure 1: Specific ocular morbidities in Chepang children.

\section{Discussion}

In the present study, the prevalence of ocular morbidities, were similar to the study done on chepang [12]. Refractive error was the leading cause of visual impairment in the present study population followed by blepharitis. In our study, the prevalence of refractive error among chepang children was $15 \%$, which was like Pokharel et al. [18]. The prevalence of astigmatism was $6.6 \%$ in our study. The high prevalence of astigmatism in our study may be explained by the fact that astigmatism is correlated with myopia, and myopia has a direct relationship with higher education [19]. In the Pokharel (2000) report, the prevalence of refractive error was reported $4.8 \%$ (hyperopia in $1.4 \%$, myopia $1.2 \%$, and astigmatism $2.2 \%$ ). The prevalence of refractive error was found higher in our study compared to Pokharel et al. [10]. The prevalence of myopia was only $4.1 \%$. These numbers are staggering considering the rising epidemics of myopia all around the world [20]. Far from gadget could be the biggest reason among all [21].

Though our study showed a slight increment in the prevalence of refractive error compared to those done earlier, it is still less compared to other study done in urban areas and hospital set up. This might be due to less exposure of Chepang children to gadgets, laptops and computers. They have adequate outdoor activities exposure.

Kaiti et al. [22] conducted a screening camp in rural area of Nepal and found the prevalence of refractive error to be $48.41 \%$. The most prevalent was astigmatism followed by myopia. $43.8 \%$ had cataract, $10.65 \%$ had conjunctivitis, $12.31 \%$ had pterygium, $0.79 \%$ had amblyopia, and $0.79 \%$ had chronic dacryocystitis
[22]. These findings were found to be higher than our study. In a study [10], cataract (35.8\%) was most prevalent ocular morbidity among chepang. $7.49 \%$ had glaucoma suspect, $7.16 \%$ had chronic dacryocystitis. Of 97 children of age group 6 to 17 years, myopia was only present on $7(7.21 \%)$ children. These finding were found to be higher than our study. The prevalence of blepharitis was $(6.67 \%)$ in our study. Poor hygiene among Chepang children was the attributing factor for blepharitis and conjunctivitis including other ocular surface disorder.

Anterior segment abnormalities are more prevalent among Chepang children than refractive error compared to other children who show more problem in refractive error.

It is evident that these group of children have poor hygiene, poor dietary habits and less awareness on ocular hygiene and care due to which they are more prone to anterior segment abnormalities and infectitious conditions. What we can conclude better is the prevalence of refractive error, keeping an eye on epidemic of myopia and global threat of refractive error.

\section{Conclusion}

Ocular morbidities are more prevalent among chepang children. There should be accessibility of eye health service at these remote areas and timely vision screening programs must be conducted among these school going children. Since, uncorrected refractive error and other ocular morbidities resulting in visual impairment have negative impact visual performance and overall quality of life, eye care should be made integral part of primary health care and primary health care workers must be trained in eye care so that appropriate management at local level can be instituted. 


\section{References}

1. Paudel P, Ramson P, Naduvilath T, Wilson D, Phuong HT, et al. (2014) Prevalence of vision impairment and refractive error in school children in Ba Ria - Vung Tau province, Vietnam. Clin Exp Ophthalmol 42(3): 217-226.

2. Edussuriya K, Sennanayake S, Senaratne T, Marshall D, Sullivan T, et al. (2009) The prevalence and causes of visual impairment in central Sri Lanka the Kandy Eye study. Ophthalmology 116(1): 52-56.

3. Katibeh M, Pakravan M, Yaseri M, Pakbin M, Soleimanizad R (2015) Prevalence and Causes of Visual Impairment and Blindness in Central Iran, The Yazd Eye Study. J Ophthalmic Vis Res 10(3): 279-285.

4. Naidoo KS, Leasher J, Bourne RR, Seth R Flaxman, Jost B Jonas, et al (2016) Global vision impairment and blindness due to uncorrected refractive error, 1990e2010. Optom Vis Sci 93(3): 227-234.

5. Pascolini D, Mariotti SP (2012) Global estimates of visual impairment: Br J Ophthalmol 96(5): 614e618.

6. Holden BA, Fricke TR, Wilson DA (2016) Global prevalence of myopia and high myopia and temporal trends from 2000 through 2050 Ophthalmology 123(5): 1036-1042.

7. Pokharel GP, Negrel AD, Munoz SR, Ellwein LB (2000) Refractive error study in children: results from mechi zone, Nepal. Am J Ophthalmol 129(4): 436-444.

8. Zhao J, Pan X, Sui R (2000) Refractive error study in children: results from Shunyi District, China. Am J Ophthalmol 129: 427-435.

9. Maul E, Barroso S, Munoz SR (2000) Refractive error study in children: results from La Florida, Chile. Am J Ophthalmol 129: 445-454.

10. Dandona R, Dandona L (2001) Refractive error blindness. Bull World Health Organ 79: 237-243.

11. Negrel AD, Maul E, Pokharel GP, Zhao J, Ellwein LB (2000) Refractive error study in children: sampling and measurement methods for a multicountry survey. Am J Ophthalmol 129: 421-426.
12. Nepal Netra Jyoti Sangh: Home " Vision 2020 » Disease Burden » Childhood Blindness.

13. Raju Kaiti (2017) "Uncorrected Refractive Error and Associated Childhood Visual Impairment - Any new steps for prevention?" Ophthalmology and Vision Science 1(4): 167-170.

14. Kaiti, Raju \& Pradhan, Asik \& Shrestha, Pooja (2018) Pattern and Prevalence of Refractive Error and Secondary Visual Impairment in Patients Attending a Tertiary Hospital in Dhulikhel. Kathmandu University Medical Journal 16: 114-119.

15. Bfeine D, Caughley, R, Shrestha D (2012) Chepang Then and Now: Life and Change among the Chepang of Nepal. Blurb Books San Francisco, CA.

16. Ghimire M (2015) Health Status of Children of Chepang and Other Communities of Nepal. Journal of Advanced Academic Research 1: 2428.

17. Ganesh Sharma, Badri Aryal (2016) Household Economies of Chepang People in Chitwan.Economic literature Vol. XIII 39-45.

18. Pokharel, Amrit \& Kandel, Himal \& Shrestha, Priyanka (2017) Pervasive Blindness and ocular morbidity in the Chepang people of Nepal. Nepalese Journal of Ophthalmology 8(2): 17021.

19. Dandona R, Dandona L, Srinivas M 2002) Moderate visual impairment in India: the Andhra Pradesh eye disease study. Br J Ophthalmol 86(4): 373-377.

20. Holden B, Fricke TR, Wilson DA, Jong M, Naidoo KS, et al. (2016) Global prevalence of myopia, high myopia, and temporal trends from 2000 to 2050. Ophthalmology 123: 1036-1042.

21. Rose KA, Morgan IG, Ip J, Kifley A, Huynh S, Smith W, et al. (2008) Outdoor activity reduces the prevalence of myopia in children. Ophthalmology 115(8): 1279-1285.

22. Kaiti, Raju \& Shyangbo, Ranjila \& Sharma, Indra (2020) Overview of a Screening Camp in Rural Area of Nepal-A Camp Report.

\section{Your next submission with Juniper Publishers will reach you the below assets}

- Quality Editorial service

- Swift Peer Review

- Reprints availability

- E-prints Service

- Manuscript Podcast for convenient understanding

- Global attainment for your research

- Manuscript accessibility in different formats

( Pdf, E-pub, Full Text, Audio)

- Unceasing customer service

Track the below URL for one-step submission https://juniperpublishers.com/online-submission.php 